\title{
ROSJA - „PIERWSZA MIŁOŚĆ I WIĘZIENIE”. KONFRONTACJA Z PRZESZŁOŚCIĄ W DZIENNIKACH IGORA GUBERMANA
}

\author{
RUSSIA - „THE FIRST LOVE AND THE PRISON”. \\ CONFRONTATION WITH THE PAST \\ IN IGOR GUBERMAN'S DIARIES
}

\section{AGNIESZKA LENART}

\begin{abstract}
AвStRAct. The article focuses on the relationship with the past, which is seen from the point of view of the emigrant, both Russian and Jewish, and his complex identity. The analysis is done on the basis of Igor Guberman's Diaries, in which an ambivalent attitude to the homeland is observed.
\end{abstract}

Keywords: Igor Guberman, Jerusalem Diaries, Russia, identity

Agnieszka Lenart, Uniwersytet Śląski, Katowice - Polska, agnieszka.lenart@us.edu.pl

ORCID ID: 0000-0002-7467-2788

Głównym paradygmatem myśli żydowskiej i twórczości literackiej Żydów jest doświadczenie migracji i sytuacja diaspory, twierdzi Olaf Terpitz, dokonując przeglądu rosyjskojęzycznej literatury emigracyjnej lat 90 . w kontekście transferu kulturowego [Терпиц 2008: 347]. Oprócz przekroczenia granic - fizycznych, ideologicznych i lingwistycznych, jak konstatuje autor, jednym z ważniejszych wyznaczników masowej emigracji Żydów z ZSRR jest skomplikowany proces wzajemnego przenikania się obrazów Rosji czy Związku Radzieckiego z obrazem nowego miejsca, dychotomiczny podział rzeczywistości na przeszłość „tam” i teraźniejszość „tutaj”.

Przestrzeń literacka dla wielu pokoleń emigrantów była i jest miejscem refleksji na temat rodzimej kultury, tożsamości, poszukiwania korzeni, polemik o życiu emigranta i problemach typowych dla sytuacji kulturowo-duchowego przemieszczania się. Każdy z emigracyjnych twórców na swój sposób przeżywa i literacko wyraża nostalgię. W pierwszej fazie pobytu w nowym miejscu często dominują opisy dotychczasowej ojczyzny, którym towarzyszą: tęsknota za krajem, żal z powodu konieczności wyjazdu, aktualne problemy adaptacyjne, które stopniowo wypierane są przez nowe wątki, dotyczące oswajanej rzeczywistości. Rosyjsko-izraelskim przykładem takiego stanu rzeczy będzie twórczość Diny Rubiny. Zupełnie odmienne stanowisko reprezentuje Grigo- 
rij Kanowicz, który na początku lat 90. zamieszkał w Izraelu, jednak twórczo wiernie oddany jest swojej Jeruszalaim de Lite. Jak w ten trudny emigracyjny dyskurs wpisuje się pozornie lekka poezja Gubermana, poety i prozaika, dysydenta, "chuligana rosyjskiej poezji"?

Igor Guberman urodził się w 1936 roku w Charkowie. Zdobywając wykształcenie techniczne jako elektryk, a później praktykując w tym zawodzie, poeta stale rozwijał swoją literacką pasję, pisał pod pseudonimami: I. Mironow, Igor Garik [Чупрынин 2008: 245-246]. „У Губермана абсолютно образцовая биография для диссидента-шестидесятника. Он - физик по образованию, выучился в институте на инженера железнодорожного транспорта, но остался лириком в душе" - tak sylwetkę Gubermana zaprezentowała telewizja NTW, informując o 75 rocznicy urodzin poety [NTV 2011].

W latach 50. Guberman zaprzyjaźnił się z Aleksandrem Ginzburgiem i aktywnie uczestniczył w działaniach kultury niezależnej. Za udział w ruchu podziemia został później skazany na pięć lat zesłania na Syberię. Obozowa rzeczywistość natchnęła twórcę do prowadzenia dziennika. Zapiski zostały wydane w 1988 roku pod wspólnym tytułem Spacery wokół baraku (Прогулкu вокруг барака).

Giennadij Jewgrafow (Gutman), redaktor czasopisma „Wiesti”, znawca literatury srebrnego wieku, wspominając przyjacielskie relacje Dawida Samojłowa z Igorem Gubermanem, przywołuje poetycki dialog poetów, mistrza i ucznia. Wypowiedź Samojłowa:

Какой уютный дом -

зачем его бояться!

Где манит огонек, почти

всю ночь светясь.

И хочется пойти,

и хочется сознаться

И правду объяснить

про каждого из нас.

I odpowiedź Gubermana:

В борьбе за народное дело

Я был инородное тело [cyt. za: Евграфов 2013]

Władze sowieckie rzeczywiście uznały Gubermana za "ciało obce”. Poeta w 1988 roku został ekspatriowany do Izraela [Paszt-Kowalska 2012: 124]. „Живу в Иерусалиме, работаю в Тель-Авиве у Эдика Кузнецова в газете «Вести». Редакционная машина заезжает за мной и другими иерусалимцами, через час мы в Тель-Авиве. Езжу выступать по всему миру. Читаю 
гарики - слушателей хватает" - cytuje słowa poety, oswajającego izraelską rzeczywistość Jewgrafow [2013].

Igor Guberman w Izraelu pisze tzw. gariki - krótkie żartobliwe wierszyki, które początkowo nazywał dazibao (z chińskiego nazwa ta tłumaczona jest jako gazetka wielkich znaków). Określenie to, jak twierdzi poeta, brzmiało zbyt absurdalnie w połączeniu z przymiotnikiem „izraelskie” - pierwszy zbiór czterowierszy nosił właśnie tytuł Izraelskie dazibao. Ostatecznie wiersze zyskały nazwę garików od zdrobniałej formy imienia poety [Чупрынин 2009: 272; Paszt-Kowalska 2012: 124]. Zamiłowanie do tetrastychów rozbudziła w Gubermanie poezja Iwana Miatlewa i Dona-Aminado Szpolańskiego.

Lucjan Suchanek w monografii poświęconej sylwetce Jurija Drużnikowa, również dysydenta, - przy pomnijmy, że Drużnikow wyjechał z ZSRR w 1987 roku, a więc rok wcześniej od Gubermana - wspomina o powszechnej w emigrantologii tezie, „,że pisarz rosyjski na emigracji jest zjadany przez nostalgię, a oderwany od korzeni i od czytelnika zawisa w próżni, nie ma skąd czerpać soków dla swej twórczości" [Suchanek 2007: 7]. Drużnikow nie zgadzał się z tym stanowiskiem, twierdził, cytując fragment wiersza Lermontowa Родина - „Люблю родину я, но странною любовью!” [Лукшич 2001], że „nieważny jest czynnik nostalgii”, „najlepiej jest pisać, znajdując się w oddali, zarówno geograficznie, jak i historycznie" [Suchanek 2007: 7]. Dla poety Ameryka szybko stała się domem.

Igor Guberman, jak sądzę, podziela pogląd Drużnikowa. Dla poety pobyt w Jerozolimie to czas twórczo bardzo intensywny. Guberman wydał tam tysiące garików i dziewięć zbiorów Dzienników Jerozolimskich, chociaż w Przedmowie do ósmego autor pisał, że plan, dotyczący dzienników został już wyczerpany [Guberman 2012]. W przypadku Gubermana wysiedlenie do Izraela oznaczało powrót do korzeni, do ojczyzny przodków, być może również ten argument ułatwił poecie asymilację (zdecydowanie należy podkreślić, że nie była to akulturacja).

Wielu emigracyjnych twórców podpisuje się obecnie pod określeniem kosmopolita [Чупрынин 2007: 246]. Sergiej Czuprynin, definiując pojęcie kosmopolityzmu w literaturze, twierdzi, że "dla pisarza rosyjskiego to przyjemność być obywatelem świata" [Чупрынин 2007: 246]. Zarówno wielu literatów, jak i ich czytelników, twierdzi Czuprynin, współcześnie często żyje na dwa domy. Autor słownika wymienia przy tym nazwiska Borysa Akunina, Wiaczesława Kozakiewicza, Borysa Chazanowa, Mariny Palej, Marii Rybakowej, ale także Jewgienija Jewtuszenko czy Diny Rubiny: „[их] все больше волнует вибрация жизни человека, интеллектуала на грани между двух стран" [Чупрынин 2007: 247]. Być może w wielu przypadkach sprzyjają takiej kategoryzacji problemy z jednoznacznym określeniem własnej tożsamości. 
Drużnikow w monografii Suchanka również jest kosmopolitą. A jeśli chodzi o Gubermana? Poeta zdecydowanie łączy dwa światy. Izrael traktuje jako swój dom, w którym jest mu dobrze, ale to właśnie Rosję nazywa prawdziwą ojczyzną:

Дом мой - Иерусалим, но Россию продолжаю считать и ощущать главной родиной. Поэтому в душе ничего не раздваивается - у меня две родины: слишком много здесь прожил, знаю. Поэтому я везде дома [...]. Хотя я там остаюсь русским. Я не израильтянин и израильской жизнью практически не живу [Lenart 2014: 147].

Liryczne "ja” u Gubermana to homo viator łączący dwa miejsca, ale jakby oddalone i oddzielone. Wyczuwa się jednak w tej poezji pewną zgodę na takie rozdwojenie. Podmiot liryczny nie jest raczej nomadą - postmodernistycznym wędrowcem, rozdartym tożsamościowo, który trwa gdzieś w zawieszeniu, nie przytłaczają go trudności aklimatyzacyjne, odmienność kulturowa, nieznajomość języka [por. Wołodźko 1995: 45]. Ten homo viator był "tam”, następnie przewędrował "tutaj” i znalazł pewien spokój. Rosyjsko-izraelskie motywy w Dziennikach płynnie się przeplatają i uzupełniają, chociaż dominują $\mathrm{w}$ tekście sytuacje typowe raczej dla rosyjskojęzycznej alii w Izraelu, a więc te bliższe autorowi, który jednoznacznie określa siebie jako Rosjanina, nieżyjącego izraelską codziennością.

Nostalgia, jak nam się wydaje, najgłębiej wybrzmiewa w trzech pierwszych zbiorach. A podtytuł pierwszego z nich wyznacza kierunek rozważań podmiotu lirycznego: „Россию увидав на расстоянии, / грустить перестаешь о расставании" [Губерман 2011].

„Ja" patrzy na Rosję z perspektywy nowej izraelskiej rzeczywistości i zamierza przestać tęsknić oraz przeżywać moment wyjazdu. Podmiot liryczny oszczędza odbiorcy tych wrażeń, podejmuje męską decyzję i doprecyzowuje swoją postawę wobec zastanej rzeczywistości i reguł nią rządzących [Kowalski 2007: 152]. Bezwzględną zgodę na taki stan rzeczy znajdujemy w pierwszym wersie kolejnego tetrastychu: „В эту землю я врос окончательно”. Decyzja o wyjeździe nie była jednak dobrowolna. Bohater liryczny ma poczucie odtrącenia, osierocenia, nazywa siebie wygnańcem bez możliwości powrotu:

Изгнанник с каторжным клеймом,

отъехал вдаль я одиноко

за то, что нагло был бельмом

в глазу всевидящего ока [Губерман 2011]

Postawa „ja” jest zbieżna z założeniami wielu uchodźców, reprezentujących emigrację rosyjską lat 70. i 80. „[...] znikoma część emigrantów trzeciej fali, a w tym i pisarzy, o czym pisze Alicja Wołodźko w monografii $\mathrm{Pa}$ sierbowie Rosji, opuszczała ZSRR z przeświadczeniem, że wyjeżdża czasowo 
i wcześniej lub później wróci. Emigracja lat 70. i 80. była w znacznej części wychodźstwem żydowskim. Wyjeżdżano po uzyskaniu wizy izraelskiej, która była warunkiem zgody władz na stały wyjazd z ZSRR. Oznaczało to opuszczenie - bezpowrotne starego kraju i wybór nowej ojczyzny" [Wołodźko 1995: 28].

Podmiot liryczny pogodził się z koniecznością zasilenia rosyjskiej alii w Izraelu, nie znaczy to jednak, że nie czuje się wykorzeniony. „Moja ziemia odtrąciła nas, krnąbrnych pasierbów, i bez żalu patrzyła, jak odchodzimy" pisał Władimir Maksimow, przymusowo wysiedlony z ZSRR [Wołodźko 1995: 5]. U Gubermana nawet Bóg jest bezradny:

Бог лежит больной, окинув глазом

дикие российские дела,

где идея вывихнула разум

и, залившись кровью, умерла [Губерман 2011]

Choroba Boga, krew, śmierć świadczą o beznadziejnej sytuacji podmiotu lirycznego, który ubolewa nad swoim losem, ale także martwi się o pozycję swojej ojczyzny-Rosji, gdzie panuje dziki chaos i zakłamanie:

Вожди России свой народ

во имя чести и морали

опять зовут идти вперед,

а где перед, опять соврали [Губерман 2011]

W kolejnych wersach liryczne „ja” utożsamia się ze społecznością żydowską, która nie znalazła w Rosji odpowiedniego miejsca, aby zbudować tam solidny dom:

Прав еврей, что успевает

на любые поезда,

но в России не свивает

долговечного гнезда [Губерман 2011]

Znajdujemy również porównania podmiotu lirycznego i jego współtowarzyszy - być może chodzi tutaj o społeczność żydowską, ale także o społeczność homo sovieticus i jej kolektywne myślenie - do trawy, która podobnie jak w bajce-alegorii Wsiewołoda Garszyna traktowana jest przedmiotowo, bez prawa głosu:

В России жил я, как трава, и меж такими же другими, сполна имея все права без права пользоваться ими. 
Wyczuwa się u Gubermana rosyjską mentalność, zachwyt literaturą, sentyment do długich rozmów w komunalnych kuchniach, pociąg do alkoholowych libacji. Podmiot liryczny w ten sposób integruje się z narodem rosyjskim, staje się jego częścią. Miłość do dawnej ojczyzny wydaje się być bezwzględna, również brutalna i wymagająca wyrzeczeń:

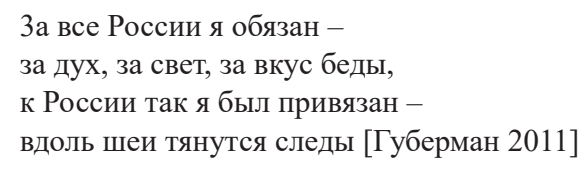

За все России я обязан -

за дух, за свет, за вкус беды,

к России так я был привязан -

вдоль шеи тянутся следы [Губерман 2011]

Są także w Dziennikach miejsca, gdzie krótkie czterowiersze przypominają kolaż, na który składają się różne odcienie tożsamości lirycznego "ja”, gdzie zauważalny jest wyraźny podział na naród rosyjski i Żydów, na "nich” i na „nas”, na przestrzeń „tutaj” i „tam”. Spotykamy w tekście określenia „чужестранство” dla określenia rosyjskiej ziemi i „собственная среда” „исконное пространство" definiujące Izrael:

Здесь мое исконное пространство, здесь я гармоничен, как нигде, здесь еврей, оставив чужестранство,

мутит воду в собственной среде [Губерман 2011]

Guberman nie dzieli świata na bezwzględnie czarny i biały, złą Rosję i harmonijny Izrael, choć bardzo często wykorzystuje taką zasadę kontrastu. Jest to raczej $\mathrm{w}$ wielu przypadkach ambiwalentne spojrzenie na rosyjsko-izraelską rzeczywistość [Olejniczak 1992: 90]. Poeta kreuje więc obraz ukochanej Rosji, umiłowanej niezapomnianym silnym uczuciem, ale również miejsca z totalitarną przeszłością, gdzie „wszechwidzące oko” staje się symbolem ograniczonej wolności i niezależności, gdzie nie było miejsca dla mniejszości żydowskiej („Россия для души и для ума - как первая любовь и как тюрьма") [Paszt-Kowalska 2012: 124]. Niebezpodstawnie zatem anglojęzyczna Wikipedia pisze o miłości i nienawiści autora do Rosji („the author's love-hate relationship with Russia"). Podobnie, bo nie do końca idealnie opisuje poeta Izrael. Z jednej strony jest to kraj, gdzie podmiot liryczny odnajduje spokój i schronienie, z drugiej zaś - zmęczony życiem w izraelskim tyglu, zarzuca Bogu, że zbyt pochopnie podjął decyzję, czyniąc społeczność żydowską „narodem wybranym”.

Устав от евреев, сажусь покурить

и думаю грустно и мрачно,

что Бог, поспеша свою книгу дарить,

народ подобрал неудачно [Губерман 2011] 
Gdy obserwujemy dwoistość obrazu Rosji i Izraela u Gubermana, nasuwa się dygresja, zbieżna z teorią Georga Simmela, którego koncepcje filozoficzne nierzadko dotyczą interakcji przestrzeń-człowiek-społeczeństwo. Tak naprawdę przecież to działalność ludzka kreuje otoczenie, nadaje sens przestrzeni [Jałowiecki 2000: 241]. W poezji Gubermana ta równowaga jest zachwiana - przestrzeń zostaje zniekształcona - poprzez system polityczny, zakłamanie rządzących, stereotypy. Idąc dalej tropem Simmela, rzeczywistości „przedtem” i „potem” w Dziennikach nie łączy most, który prowadzi na lepszą stronę. Są to raczej drzwi, które w odróżnieniu od niemej ściany - twardej granicy, stają się symbolem nieustannej wymiany [Simmel 2006: 251-252]. Te drzwi u Gubermana nigdy nie są zamknięte, nie pozwala na to rozszczepiona tożsamość i bezwzględne poszanowanie języka rosyjskiego. Władimir Nabokov zapytany, czy wróciłby do Rosji odpowiedział stanowczo: „Я никогда не вернусь, по той простой причине, что вся Россия, которая мне нужна, всегда со мной: литература, язык и мое собственное русское детство" [Шишкин 1999]. Guberman przywołuje podobne argumenty, podkreślając przede wszystkim miłość do ojczystego języka: „Вы знаете, если я чего и патриот в этой жизни, то русского языка" [Васильев 2011].

\section{Bibliografia}

Васильев Ю. 2011. Поэт Игорь Губерман - о лучшем за семьдесят пять лет, źródło elektroniczne: http:/ /inosmi.ru/social/20110708/171764243.html (dostęp 7.10.2018).

Губерман И. 2009. Первый иерусалимский дневник. Второй иерусалимский дневник, Москва: Эксмо.

Губерман И. 2011. Гарики из Иерусалима Книга странствий (сборник), źródło elektroniczne: https:/ / mybook.ru/author/igor-guberman/gariki-iz-ierusalima-kniga-stranstvijsbornik/ (dostęp 7.10.2018).

Губерман И. 2012. Предисловие, Восьмой Иерусалимский дневник, „Иерусалимский журнал", nr 43, źródło elektroniczne: http://magazines.russ.ru/ier/2012/43/g4.html (dostęp 7.10.2018).

Евграфов Г. 2013. Абрам Хайям, „Независимая газета”, 24.01.2013, źródło elektroniczne: http:/ / www.ng.ru/ng_exlibris/2013-01-24/4_gyberman.html (dostęp 7.10.2018).

Лукшич Л. 2001. Юрий Дружников: Эмиграция: сладкие и горькие пилюли, „Лебедь. Независимый бостонский альманах", 15.07.2001, źródło elektroniczne: http:/ lebed. com/2001/art2584.htm (dostęp 7.10.2018).

Терпиц О. 2008. „Здесь” и "там”. Аспект „культурного трансфера” в литературном дискурсе 1990-х годов, [w:] О. В. Будницкий (red.), Еврейская эмиграция из России, Москва: Росспэн.

Чупрынин С. 2009. Новый путеводитель. Русская литература сегодня, Москва: Время.

Чупрынин С. 2008. Зарубежье. Русская литература сегодня, Москва: Время.

Шишкин М. 2011. Русская Швейцария, źródło elektroniczne: http:/ / magazines.russ.ru/ druzhba/2001/4/shish.html (dostęp 7.10.2018). 
Jałowiecki B. 2000. Przestrzeń społeczna, [w:] Z. Bokszański, H. Domański (red.), Encyklopedia socjologii, t. 3, Warszawa: Oficyna Naukowa.

Kowalski T. 2007. Być Żydem (o tożsamości bohaterów prozy Henryka Grynberga), [w:] A. Gleń, I. Jokiel, M. Szladowski (red.), Literatura a/i tożsamość w XX wieku, Opole: Wydawnictwo Uniwersytetu Opolskiego.

Lenart A. 2014. Rosyjska alija w Izraelu. „Od samozachwytu do samonegacji”, [w:] A. Raźny (red.), Tożsamość, indywidualizm, wspólnotowość w kulturze rosyjskiej, Kraków: Wydawnictwo Uniwersytetu Jagiellońskiego.

NTV 2011.07.07, 11:50 (program TV), źródło elektroniczne: https:/ /www.ntv.ru/novosti /232719/ (dostęp 7.10.2018).

Olejniczak J. 1992. Arkadia i małe ojczyzny. Vincenz - Stempowski - Wittlin - Miłosz, Kraków: Oficyna Literacka.

Paszt-Kowalska I. 2012. Транснационализм в художественной интерпретации Игоря Губермана (Иерусалимский дневник), [w:] К. Янашек, Й. Митурска-Бояновска, А. Шунков, Б. Родзевич (red.), Ното Сотmипісапs II: Человек в пространстве межкультурной коммуникациии, Szczecin: Grafform.

Simmel G. 2006. Most i drzwi. Wybór esejów, przeł. M. Łukasiewicz, Warszawa: Oficyna Naukowa.

Suchanek L. 2007. Anioty, biesy i prawda. Pisarstwo Jurija Drużnikowa, Kraków: Wydawnictwo Uniwersytetu Jagiellońskiego.

Wołodźko A. 1995. Pasierbowie Rosji. O prozaikach trzeciej fali, Warszawa: Warszawska Oficyna Wydawnicza "Gryf”. 